\title{
Biosecurity Perspectives in Oral and Maxillofacial Radiology in Times of Coronavirus disease (COVID-19): a Literature Review
}

\author{
Perspectivas de Bioseguridad en Radiología Oral y Maxilofacial en Tiempos \\ de Enfermedad por Coronavirus (COVID-19): Revisión de la Literatura
}

\author{
Nelí Pieralisi'; Gustavo Nascimento de Souza-Pinto'; ${ }^{2}$ Lilian Cristina Vessoni Iwaki'; \\ Mariliani Chicarelli-Silva ${ }^{1} \&$ Elen de Souza Tolentino ${ }^{1}$
}

\begin{abstract}
PIERALISI, N.; SOUZA-PINTO, G. N.; IWAKI, V. L. C.; CHICARELLI-SILVA, M. \& TOLENTINO, S. E. Biosecurity perspectives in oral and maxillofacial radiology in times of coronavirus disease (COVID-19): a literature review. Int. J. Odontostomat., 15(1):77-81, 2021.
\end{abstract}

ABSTRACT: The aim of this work was to report biosecurity measures in the Oral and Maxillofacial Radiology (OMR) clinic in the current context of COVID-19, based on a literature review. An electronic search for scientific papers was performed using PubMed, Embase, Web of Science, and Scopus database. Although the literature related to care in the OMR clinic regarding COVID-19 is still scarce, this unprecedented scenario created by the pandemic generated an urgent need for measures to prevent the transmission of the virus. Dentists are at maximum risk of contagion and, although the practice of OMR generally does not produce aerosols, radiologists and technicians are continually in contact with body fluids, such as saliva. In addition, imaging exams are often indispensable for emergency or elective dental diagnosis and treatment. Training in infection control practices during major outbreaks of infectious diseases should be quickly reinforced and dental settings have unique characteristics that warrant specific infection control considerations. Some recommendations have been proposed and were discussed, which cover patient flow, equipment handling and environment, radiographic technique and processing, personal protective equipment and preparation and issuance of radiological reports and access to exam results. Due to the COVID-19 pandemic, biosecurity measures in the routine of the OMR clinic are indispensable to enable emergency dental care and the perspectives of returning to elective treatment. Biosecurity measures and staff training at the OMR clinic should be instituted immediately, since imaging exams are an important and often indispensable part of dental diagnosis and treatment.

KEY WORDS: biosecurity, COVID-19, dental clinic, oral radiology., SARS- CoV-2, cirugía oral y maxilofacial, epidemiología, trauma maxilofacial, infección.

\section{INTRODUCTION}

In early 2020, a novel RNA coronavirus (SARSCoV-2) was released as the etiologic agent of Severe Acute Respiratory Syndrome Coronavirus 2 (SARSCoV-2) - COVID-19 (Li et al., 2020). The severity of the disease has been attributed to the angiotensinconverting enzyme 2 (ACE2) of the epithelial cells of the lung, which works as a cellular receptor for the virus. Although lung cells are the main target, salivary gland ducts are also affected, causing the production of contaminated saliva (Li et al., 2020; Rothan \& Byrareddy, 2020; Lee et al., 2020), Cases of the disease, first diagnosed in China in December 2019, have spread to countless countries and a pandemic has been established by the World Health Organization (WHO) on 11 March (World Health Organization, 2020a). At the time, there were more than 21.2 million confirmed COVID-19 cases including 761000 deaths (World Health Organization, 2020b). This emergency context of international public health evidenced the high transmissibility of SARS-CoV-2 through contact with the oral, nasal and ocular mucous membranes, in addition to respiratory transmission, considered the main mode of transmission (Rothan \& Byrareddy).

${ }^{1}$ DDS, MSc, PhD, Professor, Department of Stomatology and Oral Radiology, State University of Maringá, PR, Brazil.

${ }^{2}$ DDS, MSc, PhD, Department of Stomatology and Oral Radiology, State University of Maringá, PR, Brazil.

Received: 2020-12-10 Accepted: 2020-12-15 
PIERALISI, N.; SOUZA-PINTO, G. N.; IWAKI, V. L. C.; CHICARELLI-SILVA, M. \& TOLENTINO, S. E. Biosecurity perspectives in oral and maxillofacial radiology in times of coronavirus disease (COVID-19): a literature review. Int. J. Odontostomat., 15(1):77-81, 2021.

The relevance of respiratory transmission is based on the fact that aerosol droplets, emitted by people infected by sneezing, coughing or by simple conversation, are stabilized in the air through coalescence with the viral particles for up to three hours (Peng et al., 2020a; Setti et al., 2020; van Doremalen et al., 2020; World Health Organization, 2020c). Although contagion from an asymptomatic individual is being discussed by $\mathrm{WHO}$, isolating and social distancing measures have been adopted in many countries (Hurley \& Neligan, 2020). Thus, situations that promote interpersonal proximity inspire protective behaviors (van Doremalen et al.). Dental professionals, who work in an environment where droplets and aerosols are produced in a minimum field radius, are at maximum risk of contagion (Meng et al., 2020; Peng et al.).

Transmission in the workplace is suspected to be the presumed infection mechanism for health professionals (29\%) (Wang et al., 2020). For this reason, advancing with this unprecedented global challenge, classroom lessons and dental school clinics' activities have been temporarily suspended (Pontual et al., 2020), reduced or changed according to each country or region, as well as several community dental clinics have restricted their activities (American Dental Education, 2020) with priority to urgent and emergency dental care in some places (Hurley \& Neligan; Sociedad de Radiologia Oral y Máxilofacial de Chile, 2020). This makes preparation of the sector essential, providing for a gradual return of elective procedures in the usual flow and pace before the pandemic. Therefore, it is necessary to develop a conduct guide that enables dental treatments, including educational ones, within this new reality in biosecurity (BSC).

The adoption of BSC measures that guarantee not only the safety of patients, but of all members of the health and education team is urgent (Wang et al.). In this context, Oral and Maxillofacial Radiology (OMR) is inserted, because, although it does not produce aerosols, it requires continuous contact with body fluids, such as saliva and blood (da Silva et al., 2003). An investigation found that only $40 \%$ of radiology department professional staff have sufficient knowledge of infection control practice (Peng et al., 2020b). Therefore, precautions with BSC in the OMR clinic should be urgently instituted, since imaging exams are an important and often indispensable part of diagnosis and treatment. Thus, the present study aims to expose and suggest which BSG measures are recommended in the OMR clinic in the current context of COVID-19, based on a literature review.

\section{Data source}

An electronic search for scientific papers was performed using PubMed, Embase, Web of Science, and Scopus database. A broad search strategy was undertaken using the keywords (Infection Control, Dental AND covid-19 AND (y_1[Filter])) AND (Radiography, Dental AND (y_1[Filter])); ((Infection Control, Dental[MeSH Terms]) AND (dental radiology)) AND (coronavirus[MeSH Terms]); (dental radiology[MeSH Terms]) AND (coronavirus[MeSH Terms]); (Infection Control, Dental[MeSH Terms]) AND (dental radiology); (Infection Control, Dental[MeSH Terms]) AND (coronavirus[MeSH Terms]). A manual search of the reference lists of all the articles retained was also made. Articles in English and Spanish were searched.

\section{REVIEW AND DISCUSSION}

The literature related to care in the OMR clinic regarding COVID-19 is still scarce. For the practice of OMR, we found only one review (Hamedani \& Farshidfar, 2020) and on letter to editor (Cral et al., 2020). In Spanish, one Journal article is available on the internet with recommendations from the Society of Oral and Maxillofacial Radiology of Chile for the indication of oral imaging exams and patient management in the context of the pandemic (Sociedad de Radiologia Oral y Máxilofacial de Chile). No original article has been published yet. Pontual et al. recently published an article on the challenges in the teaching of OMR, since classroom classes are suspended at most universities. Within the medical context, Yu et al. (2020) suggest measures to prevent crosscontamination in the radiological clinic and recommend that training in infection control practices during major outbreaks of infectious diseases such as COVID-19 be quickly reinforced. In general, the Centers for Disease Control and Prevention (2020) recognizes that dental settings have unique characteristics that warrant specific infection control considerations and that the most critical dental services must be prioritized.

\section{Equipment handling and environment}

Disinfection and/or sterilization of equipment and materials in the OMR clinic are essential for controlling the proliferation of microorganisms (Ferreira et al., 2016; Sociedad de Radiologia Oral y Máxilofacial de Chile). Fortunately, SARS-Cov-2 is easily eliminated, although it can persist on surfaces for several days 
(van Doremalen et al.) if not properly cleaned. In order to optimize this process, it is recommended that the entire work environment be vacated, i.e., everything that is not necessary for the execution of the procedure must be removed, disfavoring the retention of residues and infectious agents. This should also be applied to other environments, such as the waiting room. All surfaces of the X-ray room and adjacent areas should be disinfected with $0.5 \%$ sodium hypochlorite before and after all services, including the floor, door handles, light switch, table, support bench, and chair (Cral et al.). Additionally, more than ever the protection of surfaces with plastic barriers must be performed: radiographic films, sensors and image receptors, dental headrest, Xray cylinder and tube head, extension arm, control panel, exposure button, computer monitors, keyboard and mouse, printer, seats and positioning devices of extraoral equipment and tomographs.

The x-ray room should be well ventilated, preferably with ventilation equipment (Yu et al.). After the examination is completed, the air and contact surfaces must be thoroughly cleaned, disinfected and sterilized ( $\mathrm{Yu}$ et al.). Especially for equipment, it is important to follow the manufacturer's instructions for all cleaning and disinfection products for concentration, method of application and contact time.

\section{Patient flow}

First of all, both staff and patients should be informed of the need to stay home if they are sick (Centers for Disease Control and Prevention). Radiological examinations should preferably be performed in patients who require emergency dental treatments (Hamedani \& Farshidfar). Non-emergency dental procedures should be postponed, with the intention of reducing the number of patients treated per day to avoid cross-contact and proximity as much as possible (Cral et al.).

All BSC measures recommended for any dental care must be followed at the radiology clinic. At the clinic entrance, the patient should be instructed on the mandatory use of masks, temperature measurement (Cral et al.), use of alcohol-based hand sanitizers (70 $\%$ ethanol $(\mathrm{v} / \mathrm{v}))$ by rubbing the palms and back of the hands, fingers and nails for at least 20 seconds (Cral et al.), and the use of disinfectants or shoe protectors. Patients should be recruited gradually, avoiding crowds in the corridors and waiting room, keeping the distance from one (World Health Organization, 2020a) to two meters (Setti et al.).
Ideally, before attending the clinic, all patients should complete a pre-screening questionnaire (triage), at most one hour before the procedure. However, variably, patients arrive at the radiology clinic in a state of dental emergency, making it impossible to check their systemic condition in advance. In such cases, a quick but comprehensive assessment for COVID-19 must be performed (Hurley \& Neligan). This questionnaire should contain questions about the systemic condition and social relationships that may suggest possible contamination by the coronavirus, in addition to questions about the occurrence of fever and breathing problems (coughing or difficulty breathing) or any symptoms in the last 14 days (Cral et al.). In addition, if there was contact with at least two people with documented experience of fever or respiratory problems, with confirmed infection or coming from regions with a high incidence of the disease (Cral et al.). Finally, if you attended a meeting with many unknown people or traveled to a location with documented SARS-Cov-2 transmission (Peng et al., 2020a). Two other requirements have been added: smell and taste deficiency (Lee et al.). And, of course, it must be asked whether the patient belongs to risk groups for COVID-19, such as the elderly, hypertensive, diabetic, immunosuppressed and pregnant women. If so, they must have priority in attendance.

It is important to note that, with or without other signs or symptoms suggestive of COVID-19, the presence of pain associated with fever may have a dental origin. In these cases, the importance of differential diagnosis is emphasized and the need for the patient to be treated in a private room, with extreme attention to BSC, is reinforced. If there are other symptoms of COVID-19, the patient should be referred immediately for medical evaluation (Peng et al., 2020a), sometimes completing the dental diagnosis at the hospital

\section{Radiographic technique}

Considering that the basic requirements for radiological protection in radiodiagnosis are followed (Cral et al.), before undergoing the radiographic examination, the patient must rinse and gargle with antiseptics (Sociedad de Radiologia Oral y Máxilofacial de Chile), $0.12 \%$ chlorhexidine digluconate (Ortega et al., 2020) or $1.0 \%-1.5 \%$ hydrogen peroxide for 30 seconds (Cral et al.). The use of plastic gloves to avoid contact with equipment and materials used during the technique is recommended. Whenever possible, extra-oral techniques (panoramic and cone beam computed tomography) are preferred (Cral et al.; 
Hamedani \& Farshidfar, 2020; Meng et al.) reducing the direct handling of the "contaminated" oral cavity and also the risk of some discomfort generated by the procedure, such as nausea and cough (Cral et al.; Dave et al., 2020; Meng et al.). Even so, if it is necessary to perform one of the intraoral radiographic techniques (periapical, interproximal or occlusal), the use of films/ sensors protected by barriers and/or X-ray positioners (ideally autoclavable) remains as the best way to reduce contamination (Oliva, 2014).

For patients in urgent and emergency dental situations referred to the hospital or already hospitalized, a portable dental x-ray unit can be useful, as long as all the mentioned protection measures are maintained (Dave et al.).

The duration of the examination should be minimized as much as possible and next patient should be examined after more than 30 minutes, allowing disinfection of the surfaces and replacement of personal protective equipment (PPE) (Yu et al.).

\section{Processing exposed radiographs}

During radiographic processing, the use of plastic gloves (da Silva et al.) prevents contamination of the darkroom and processing solutions (Oliva). Plastic barriers must be removed for film processing (Oliva). The quality of the radiographic processing effluents (developer, fixer and washing water) is also important, since poor quality can alter the density and contrast of the image, making it necessary to perform new radiographs, with a new risk of contagion, in addition to new radiation exposure (da Silva et al.).

\section{Personal protective equipment (PPE)}

The use of non-absorbable disposable gowns or lab coats with long sleeves, shoes cover, medical caps, masks and gloves, as well as goggles and face shields are recommended for all procedures, even if there is no aerosol production (Sociedad de Radiologia Oral y Máxilofacial de Chile). For extra-oral radiographic techniques, a fabric lab coat may be sufficient, paying attention to its subsequent washing with disinfectant. However, a 30 GSM disposable lab coat is standardized along with the use of surgical mask, face shield and disposable gloves. For intraoral techniques and in patients with suspected or confirmed COVID-19, nonvalved N95 or FFP2 masks and goggles are indispensable. To ensure a better seal of the masks, avoid wearing makeup and growing a beard.
In the darkroom, some PPE are dispensable, keeping only the mask, fabric lab coat and plastic gloves, preventing contamination of the environment. Constant hand washing is essential (Sociedad de Radiologia Oral y Máxilofacial de Chile). If inaccessible, a hand sanitizing gel with $70 \%$ alcohol should be used (Cral et al.).

\section{Preparation and issuance of radiological reports and access to exam results}

Radiologists can perform remote diagnosis and patients can use programs or mobile apps to check the exam result (Yu et al.). Paperless systems minimize the risk of document-mediated transmission. Electronic examination application forms, informed consent for examination, and imaging data can be viewed throughout the clinic without contact with physical documents (Yu et al.). Computers, tablets or smartphones can be used in the clinic as long as they are covered with protective barriers or regularly disinfected.

\section{CONCLUSION}

Due to the COVID-19 pandemic, BSC measures in the routine of the OMR clinic are indispensable to enable emergency dental care and the perspectives of returning to elective treatment. BSC measures and staff training at the OMR clinic should be instituted immediately, since imaging exams are an important and often indispensable part of dental diagnosis and treatment.

PIERALISI, N.; SOUZA-PINTO, G. N.; IWAKI, V. L. C.; CHICARELLI-SILVA, M. \& TOLENTINO, S. E. Perspectivas de bioseguridad en radiología oral y maxilofacial en tiempo de enfermedad por coronavirus (COVID-19): Revisión de la literatura. Int. J. Odontostomat., 15(1):77-81, 2021

RESUMEN: El objetivo de este trabajo fue reportar las medidas de bioseguridad en la clínica de Radiología Oral y Maxilofacial (OMR) en el contexto actual del COVID-19, a partir de una revisión de la literatura. Se realizó una búsqueda electrónica de artículos científicos utilizando PubMed, Embase, Web of Science y la base de datos Scopus. Si bien la literatura relacionada con la atención en la clínica OMR respecto al COVID19 aún es escasa, este escenario inédito creado por la pandemia generó una urgente necesidad de medidas para prevenir la transmisión del virus. Los dentistas tienen el máximo riesgo de contagio y, aunque la práctica en la OMR generalmente no produce aerosoles, los radiólogos y técnicos están continuamente en contacto con fluidos corporales, como la saliva. Además, los exámenes por imágenes a menudo son indispensables para el diag- 
nóstico y el tratamiento dental de emergencia o electivo. La capacitación en prácticas de control de infecciones durante brotes importantes de enfermedades infecciosas debe reforzarse rápidamente y los entornos dentales tienen características únicas que justifican consideraciones específicas de control de infecciones. Se han propuesto y discutido algunas recomendaciones que cubren el flujo de pacientes, el manejo y el entorno del equipo, la técnica y el procesamiento radiográfico, el equipo de protección personal y la preparación y emisión de informes radiológicos y el acceso a los resultados de los exámenes. Debido a la pandemia de COVID-19, las medidas de bioseguridad en la rutina de la clínica OMR son indispensables para posibilitar la atención dental de emergencia y las perspectivas de volver al tratamiento electivo. Las medidas de bioseguridad y la capacitación del personal en la clínica OMR deben instituirse de inmediato, ya que los exámenes por imágenes son una parte importante y, a menudo, indispensable del diagnóstico y tratamiento dental.

PALABRAS CLAVE: bioseguridad, COVID-19, clínica dental, radiología oral.

\section{REFERENCES}

American Dental Education. Response of the Dental Education Community to Novel Coronavirus (COVID-19). Website. Chicago, American Dental Education, 2020. Available from: https:// www.adea.org/COVID19-Update/

Centers for Disease Control and Prevention (CDC). Guidance for Dental Settings. Atlanta, Centers for Disease Control and Prevention, 2020. Available from: https://www.adea.org/COVID19-Update/

Cral, W. G.; Lima, C. A. S. \& de Paula Queluz, D. COVID-19 and oral radiology. Imaging Sci. Dent., 50(2):181-2, 2020.

da Silva, F. C.; Antoniazzi, M. C. C.; Rosa, L. P. \& Jorge, A. O. C. Estudo da contaminação microbiológica em equipamentos radiográficos. Rev. Biocienc., 9(2):35-43, 2003.

Dave, M.; Coulthard, P.; Patel, N.; Seoudi, N. \& Horner, K. Letter to the editor: use of dental radiography in the COVID-19 pandemic. J. Dent. Res., 99(9):1112, 2020.

Ferreira, R. E. C.; Neto, J. R.; Antas, M. D. G. C.; Sobrinho, C. R. W. \& Perez, F. M. D. M. R. Eficácia de três substâncias desinfetantes na prática da radiologia odontológica. Rev. Bras. Odontol., 73(1):14, 2016.

Hamedani, S. \& Farshidfar, N. The practice of oral and maxillofacial radiology during COVID-19 outbreak. Oral Radiol., 36(4):400-3, 2020.

Hurley, S. \& Neligan, M. Preparedness letter for primary dental care. NHS England, 2020. Available from: https://www.england.nhs.uk/ coronavirus/wp-content/uploads/sites/52/2020/03/issue-3preparedness-letter-for-primary-dental-care-25-march-2020.pdf

Lee, Y.; Min, P.; Lee, S. \& Kim, S. W. Prevalence and duration of acute loss of smell or taste in COVID-19 patients. J. Korean Med. Sci., 35(18):e174, 2020

Li, Y.; Ren, B.; Peng, X.; Hu, T.; Li, J.; Gong, T.; Tang, B.; Xu, X. \& Zhou, $X$. Saliva is a non-negligible factor in the spread of COVID-19. Mol. Oral Microbiol., 35(4):141-5, 2020.

Meng, L.; Hua, F. \& Bian, Z. Coronavirus disease 2019 (COVID-19): emerging and future challenges for dental and oral medicine. J. Dent. Res., 99(5):481-487, 2020.

Oliva, A. H. D. Protocolo de biossegurança na clínica de radiologia odontológica. Dentistry Bachelor Degree. Araçatuba, Universidade Estadual Paulista Julio de Mesquita Filho, Faculdade de Odontologia de Araçatuba, 2014. Available from: http://hdl.handle.net/11449/ 149538
Ortega, K. L.; Rodrigues de Camargo, A.; Bertoldi Franco, J.; Mano Azul, A.; Pérez Sayáns, M. \& Braz Silva, P. H. SARS-CoV-2 and dentistry. Clin. Oral Investig., 5:1-2, 2020.

Peng, J.; Ren, N.; Wang, M. \& Zhang, G. Practical experiences and suggestions for the 'eagle-eyed observer': a novel promising role for controlling nosocomial infection in the COVID-19 outbreak. J. Hosp. Infect., 105(1):106-7, 2020.

Peng, X.; Xu, X.; Li, Y.; Cheng, L.; Zhou, X. \& Ren, B. Transmission routes of 2019-nCoV and controls in dental practice. Int. J. Oral Sci., 12:9, 2020. DOI: https://www.doi.org/10.1038/s41368-020-0075-9

Pontual, M. L. A.; do Nascimento, E. H. L.; da Cruz Perez, D. E.; Pontual, A. A. \& Ramos-Perez, F. M. Challenges in oral radiology teaching during COVID-19 pandemic. Dentomaxillofac. Radiol., 49(5):20200178, 2020.

Rothan, H. A. \& Byrareddy, S. N. The epidemiology and pathogenesis of coronavirus disease (COVID-19) outbreak. J. Autoimmun., 109:102433, 2020.

Setti, L.; Passarini, F.; De Gennaro, G.; Barbieri, P.; Perrone, M. G.; Borelli, M.; Palmisani, J.; Di Gilio, A.; Piscitelli, P. \& Miani, A. Airborne transmission route of COVID-19: why 2 meters/6 feet of inter-personal distance could not be enough. Int. J. Environ. Res. Public Health, 17(8):2932, 2020.

Sociedad de Radiologia Oral y Máxilofacial de Chile. Recomendaciones de la Sociedad de Radiología Oral y MáxiloFacial de Chile Respecto a la Indicación de Exámenes Imagenológicos Dento-Maxilofaciales y Manejo de Pacientes en Contexto de Pandemia por Coronavirus (COVID-19). Santiago de Chile, Sociedad de Radiologia Oral y Máxilofacial de Chile, 2020. Available from: https://odon.edu.uy/sitios/radiologia/wp-content/uploads/sites/26/2020/04/ Sociedad de Radiolog \%c3\%ada_Oral_Maxilofacial_COVID-19.pdf

van Doremalen, N.; Bushmaker, T.; Morris, D. H.; Holbrook, M. G.; Gamble, A.; Williamson, B. N.; Tamin, A.; Harcourt, J. L.; Thornburg, N. J.; Gerber, S. I.; et al. Aerosol and surface stability of SARS-CoV2 as compared with SARS-CoV-1. N. Engl. J. Med., 382(16):1564-7, 2020.

Wang, D.; Hu, B.; Hu, C.; Zhu, F.; Liu, X.; Zhang, J.; Wang, B.; Xiang, H.; Cheng, Z.; Xiong, Y.; et al. Clinical characteristics of 138 hospitalized patients with 2019 novel coronavirus-infected pneumonia in Wuhan, China. JAMA, 323(11):1061-9, 2020.

World Health Organization (WHO). Coronavirus Disease (COVID-19) Situation Report - 141. Geneva, World Health Organization, 2020. Available from: https://www.who.int/docs/default-source/coronaviruse/ situation-reports/20200817-weekly-epi-update1.pdf?sfvrsn=b6d49a76 4

World Health Organization ( $\overline{\mathrm{W}} \mathrm{HO})$. Modes of transmission of virus causing COVID-19: implications for IPC precaution recommendations. Geneva, World Health Organization, 2020. Available from: https:// www.who.int/news-room/commentaries/detail/modes-oftransmission-of-virus-causing-covid-19-implications-for-ipcprecaution-recommendations

World Health Organization (WHO). Rational Use Of Personal Protective Equipment (PPE) For Coronavirus Disease (COVID-19). Geneva, World Health Organization, 2020. Available from: https://www.who.int $\mathrm{dg} / \mathrm{speeches/detail/who-director-general-s-opening-remarks-at-the-}$ media-briefing-on-covid-19---11-march-2020

Yu, J.; Ding, N.; Chen, H.; Liu, X. J.; He, W. J.; Dai, W. C.; Zhou, Z. G.; Lin, F.; Pu, Z. H.; Li, D. F.; et al. Infection control against COVID-19 in departments of radiology. Acad. Radiol., 27(5):614-7, 2020.

Corresponding author:

Gustavo Nascimento de Souza Pinto

Avenida Mandacaru, 1550

CEP 87080-000

Maringá - PR

BRAZIL

E-mail: nsouzagustavo@gmail.com 